\title{
MEMBUMIKAN TUHAN: TELAAH KONSEPSI SUFISTIK WAHDAT AL-WUJUD DALAM LOKUS PERILAKU SOSIAL KEMANUSIAAN
}

\section{EARTH GOD: HAVE A SUFISTIC CONCEPTION WAHDAT AL- WUJUD IN THE LOCUS OF HUMANITY SOCIAL BEHAVIOR}

\author{
A. Syatori \\ IAIN Syekh Nurjati Cirebon
}

bangsyatori@yahoo.com

\begin{abstract}
Muhammad Ibn 'Ali Ibn Muhammad Ibn al-'Arabi al-Tha'i al-Hatimi. For Ibn al-'Arabi, wahdat al-wujud is a basic metaphysical concept which is closely related to the concept of insan alkamil (perfect human being) which is the essence of his tasawwuf teachings. The core issue in the debated wahdat al-wujud is the ontological relationship between God and nature. Wahdat al-wujud Ibn al-'Arabi starts from the assumption that God is one absolute, infinite, qadim and eternal being who is the source and origin of all that exists, has ever existed and will be. In collecting data in this article using qualitative methods with a review of relevant literature and accompanied by examples that can facilitate understanding. It is very important to explore further about the thoughts of Ibn al'Arabi, which in this case will be studied further in the article entitled Ibn al-'Arabi and the results of his thoughts. In this way, this article is expected to help academics find the concept of wahdat alwujud according to Ibn al-'Arabi.
\end{abstract}

Keyword: Ibn al-'Arabi', Wahdat al Wujud'

ABSTRAK: Muhammad Ibn 'Ali Ibn Muhammad Ibn al-'Arabi al-Tha'i al-Hatimi. Bagi Ibn al-'Arabi, wahdat al-wujud merupakan konsep dasar metafisikanya yang terkait erat dengan konsep insan alkamil (manusia sempurna) yang merupakan inti sari ajaran tasawwufnya. Persoalan inti dalam wahdat al-wujud yang diperdebatkan adalah hubungan ontologis antara Tuhan dan alam. Wahdat al-wujud Ibn al-'Arabi bertolak dari asumsi bahwa Tuhan itu adalah satu wujud mutlak, tidak terbatas, qadim dan abadi yang merupakan sumber dan asal dari semua yang ada, yang pernah ada dan yang akan ada. Dalam pengumpulan data dalam artikel ini menggunakan metode kualitatif dengan kajian literatur yang relevan dan disertai dengan contoh-contoh yang dapat memudahkan pemahaman. Penting sekali untuk didalami lebih lanjut mengenai pemikiran Ibn al'Arabi yang dalam hal ini akan dikaji lebih lanjut dalam arrtikel berjudul Ibn al-'Arabi dan Hasil Pemikirannya. Dengan begitu, artikel ini diharapkan bisa membantu para akademisi dalam menemukan konsep wahdat al-wujud menurut Ibn al-'Arabi.

Kata Kunci: Ibn al-'Arabi', Wahdat al Wujud'

\section{A. PENDAHULUAN}

Tasawwuf atau sufisme sebagai salah satu dari khazanah intelektual Islam menempatkan aspek batiniah manusia pada posisi sentral dalam berbagai tema pembahasannya. Pada saat tertentu, bahkan seringkali menghubungkan kesempurnaan batin manusia dengan wujud yang satu, yang transenden, yakni wujud Tuhan. Pada perkembangannya, tema di atas telah memunculkan berbagai konsep yang secara 
spesifik dan kompherensip membahas pola hubungan tersebut. Salah satunya yang paling berpengaruh adalah konsep wahdat al-wujud yang diperkenalkan dan dikembangkan oleh seorang sufi besar Islam dari Murcia, Andalusia, Spanyol yang bernama Muhammad Ibn 'Ali Ibn Muhammad Ibn al-'Arabi al-Tha'i al-Hatimi yang hidup pada abad ke-5 H atau abad ke-11 M (Austin, 1994: 17). Ia memiliki gelar Muhyiddin (penghidup agama) dan al-Syaikh al-Akbar (guru terbesar). Selanjutnya ia lebih dikenal dengan nama Ibn al-'Arabi.

Bagi Ibn al-'Arabi, wahdat al-wujud merupakan konsep dasar metafisikanya yang terkait erat dengan konsep insan al-kamil (manusia sempurna) yang merupakan inti sari ajaran tasawwufnya (Noer, 1995: 126). Persoalan inti dalam wahdat al-wujud yang diperdebatkan adalah hubungan ontologis antara Tuhan dan alam. Wahdat alwujud Ibn al-'Arabi bertolak dari asumsi bahwa Tuhan itu adalah satu wujud mutlak, tidak terbatas, qadim dan abadi yang merupakan sumber dan asal dari semua yang ada, yang pernah ada dan yang akan ada. Selanjutnya asumsi tersebut secara berangsurangsur mengambil bentuk acosmism yang memandang alam fenomena ini hanya sebagai bayang-bayang dari realitas yang ada di baliknya (Ali, 1997: 52). Sementara konsep insan al-kamil Ibn al-'Arabi bertolak dari pandangan bahwa segenap wujud hanya mempunyai satu realitas. Realitas tunggal yang benar-benar ada itu adalah Allah. Adapun alam semesta yang serba ganda ini hanyalah wadah tajalli dari nama-nama dan sifat-sifat Allah dalam wujud yang terbatas. Nama-nama dan sifat-sifat itu sendiri identik dengan zat-Nya yang mutlak (Ali, 1997: 50). Jadi, baik wahdat al-wujud maupun insan kamil sesungguhnya ingin menunjukkan hal yang sama tentang pola hubungan antara yang real dan yang fenomena, dimana keduanya berasal dari satu realitas, yaitu Allah SWT.

Menurut Ibn al-'Arabi, realitas tunggal itu dapat dipandang dari dua segi. Pertama, dari segi esensinya (al-haqq) yang bersifat transenden dan merupakan substansi dari semua fenomena. Kedua, dari segi nama-nama dan sifat-sifatnya (alkhalq) yang merupakan fenomena yang memanifestasikan esensi itu dan bersifat imanen (Ibn al-'Arabi, 1980, 1:24-25). Al-haqq dan al-khalq atau yang transenden dan yang imanen tidak lain hanyalah sebutan untuk dua aspek dari satu hakikat, yakni Tuhan. Kedua aspek ini muncul hanyalah sebagai tanggapan dari akal semata, namun pada hakikatnya semuanya itu satu (Ibn al-'Arabi, 1980, 1:124 dan 2:8). Tetapi ini bukan 
berarti Tuhan identik dengan alam. Ibn al-'Arabi bermaksud membedakan antara ketunggalan mutlak esensi ilahi dan ketunggalan relatif tuhan yang meliputi nama-nama polar. Dengan demikian, Ibn al-'Arabi sebenarnya ingin mengkontraskan "ketunggalan dari satu" (ahadiyyat al-ahad) dan "ketunggalan dari banyak" (ahadiyyat al-katsrah). Ibn al- 'Arabi berkata : "Berkenaan dengan diri-Nya sendiri Allah mempunyai ketunggalan dari yang satu. Tapi berkenaan dengan nama-nama-Nya Dia mempunyai ketunggalan dari yang banyak (Murata, 1999: 91).

Manusia sebagai bagian dari alam bagi Ibn al-'Arabi adalah merupakan wujud serba meliputi (al-kawn al-jami') (Murata, 1999: 61). Manusia memiliki potensi untuk memanifestasikan semua nama dan sifat Tuhan. Jadi, secara primordial, manusia merupakan makhluk teomorfis (wadah tajalli Tuhan) yang memiliki potensi untuk menerima penampakan semua nama dan sifat Tuhan. Karena dengan sifatnya tersebut, manusia dapat memperlihatkan variasi tidak terbatas nama-nama dan sifat-sifat tuhan secara utuh, bersatu dan terkonsentrasi. Berbeda dengan alam selain manusia yang hanya memanifestasikan sebagian dari nama-nama dan sifat-sifat Tuhan secara terpisah dan menyebar di berbagai tempat di alam semesta.

\section{B. METODE PENELITIAN}

Metode yang digunakan dalam penelitian artikel ini menggunakan metode penelitian kualitatif. Dengan menjelaskan secara deskriptif dan analisis tentang pemikiran dan teori Ibn al-'Arabi. Tidak halnya itu, dalam artikel ini juga dilengkapi contoh-contoh yang memudahkan untuk pemahaman. Penelitian kualitatif merupakan penelitian yang digunakan untuk menyelidiki, menemukan, menggambarkan, dan menjelaskan kualitas atau keistimewaan dari pengaruh sosial yang tidak dapat dijelaskan, diukur atau digambarkan melalui pendekatan kuantitatif.

\section{HASIL DAN PEMBAHASAN}

\section{a). Ibn al-‘Arabi, Sang Sufi Nyentrik dari Andalusia}

Dalam sejarah pemikiran Islam, terdapat dua tokoh terkemuka yang memiliki nama Ibn al-'Arabi. Yang pertama, Abu Bakr Muhammad Ibn Abd. Allah Ibn al-'Arabi al-Ma'afiri (468-543 H/1076-1148 M), seorang ahli hadits dari seville. Ia bukanlah obyek pembicaraan dalam tulisan ini. Yang kedua, Muhammad Ibn 'Ali Ibn Muhammad Ibn al-'Arabi al-Ta’i al-Hatimi, seorang sufi termasyhur dari Andalusia dan 
merupakan obyek pembicaraan dalam tulisan ini. Ia dilahirkan pada 17 Ramadhan 560 H atau 28 Juli 1165 M (Noer, 1995: 126). Ada juga yang menyebut pada 27 Ramadhan 560 H. atau 7 Agustus 1165 M. (Austin, 1994: 17), di Murcia Andalusia, Spanyol bagian tenggara, yang pada saat itu diperintah oleh seorang komandan brilian keturunan kristen bernama Muhammad bin Sa'id bin Mardanisy. Ibn al-'Arabi berasal dari keluarga Arab kuno (suku Tayy), dan ayahnya 'Ali Ibn al-'Arabi adalah orang yang mempunyai kedudukan tinggi dan berpengaruh. Keluarganya, selain mempunyai hubungan sosial dan kultural yang baik, juga memiliki kecenderungan religius yang kuat.

Pada tahun 597 H./1200 M. Ibn al-‘Arabi berada di ibukota al-Muwahhidin, Marrakesy, di mana banyak waktunya dihabiskan dengan sang penjaga dan penanggung jawab zakat, Abu Abbas dari Ceuta. Kemudian, ketika berada di Maghrib (Muharram 597 H.), ia mencapai maqam kedekatan dan mendapat visi agung di mana ia disuruh menemui seorang tertentu yang bernama Muhammad bin Hasyar dan melakukan perjalanan bersamanya ke Timur. Dan pada bulan Ramadhan 597 H. ia bersama sahabat barunya memasuki kota Bugia dan di sana bertemu dengan Abu Abd. Allah al-'Arabi bersama sekelompok orang mulia lainnya dan mendapat sebuah visi baru. Setelah mengunjungi Fez, Marrakesy dan Bugia, Ibn al-'Arabi kembali ke Tunisia pada tahun 598 H./1201 M. dan mencapai maqam spiritual lainnya. Selama menetap di sana, ia tinggal bersama sahabatnya al-Mahdawi dan menyelesaikan karyanya Insya' al-Dawa 'ir (Noer, 1995: 19). Dari Tunisia, ia melanjutkan perjalanannya ke arah timur, Mekkah, bersama sahabatnya al-Hasyar untuk melaksanakan ibadah haji. Namun terlebih dahulu singgah di Alexandria dan Kairo, Mesir. Di sana sahabatnya meninggal dunia, ahirnya ia melanjutkan perjalanannya sendirian dan tiba di Mekkah pada penghujung tahun 598 $\mathrm{H}$.

Selama di Mekkah, Ibn al-“Arabi banyak menghabiskan waktunya untuk belajar dan berdiskusi dengan banyak ulama dan para sufi di kota itu. Ia juga mulai menulis karya ensiklopedi monumentalnya al-Futuhat al-Makkiyyah dan menyelesaikan empat karyanya yang lebih pendek Misykat al-Anwar, Hilyat al-Abdal, Taj al-Rasa'il dan Ruh al-Quds. Pada tahun 601 H./1204 M. Ibn al-'Arabi meninggalkan Mekkah menuju Baghdad. Ia tinggal di sana hanya dua belas hari dan selanjutnya pergi ke Mosul dan menulis sebuah risalah 53 bab tentang signifikansi esoteris wudlu dan shalat dengan 
judul at-Tanazzulat al-Mausiliyyah (wahyu-wahyu di Mosul). Di kota ini pula ia dilantik untuk ke tiga kalinya sebagai murid al-Khidr (Noer, 1995: 21-22). Selanjutnya pada tahun 604 H./1207 M. Ibn al-'Arabi kembali ke Mekkah untuk melanjutkan studinya tentang hadits. Ia tinggal di sana setahun lebih dan kemudian melakukan perjalanan ke utara menuju Asia Kecil. Iasinggah terlebih dahulu di Aleppo untuk memberikan sertifikat pada sebuah salinan karyanya Kitab at-Tajalliyat (Austin, 1994: 43). Ahirnya, pada tahun 607 H./1210 M. ia baru tiba di Konya dan disambut dengan baik oleh penguasa Kay Kaus dan orang-orang di sana.

Ibn al-'Arabi wafat pada tanggal 28 Rabi' al-Tsani 638 H./1240 M (Austin, 1994: 51) atau 22 Rabi' al-Tsani 638 H./1234 M (Ali, 1997: 24), di Damaskus dalam usia 76 tahun. Qadhi ketua, Ibn al-Zaki dan dua muridnya ikut melaksanakan upacara pemakamannya. Ia dikebumukan di Salihiyyah, di kaki bukit Qasiyun di pekuburan pribadi Qadhi Muhyiddin Ibn al-Zaki, bagian utara kota Damaskus.

Signifikansi Ibn al-'Arabi bagi sejarah tasawwuf terletak pada dua hal. Pertama, Ibn al-'Arabi adalah jembatan atau penghubung antara dua fase historis Islam dan tasawwuf. Ia mengungkapkan ajaran-ajaran dan berbagai pandangan generasi-generasi sufi yang mendahuluinya dengan merekam secara sistematis dan rinci simpanan luas pengalaman dan tradisi lisan sufi dengan menggali khazanah istilah-istilah tekhnis dan simbol-simbol yang banyak diperkaya oleh pergaulan selama berabad-abad antara dunia muslim dan neo-hellenistik, sehingga ia wariskan pernyataan definitif ihwal ajaranajaran sufi dan juga rekaman lengkap warisan esoteris Islam. Dengan demikian, sangat mempengaruhi sufi berikutnya dan otomatis menjadi penghubung amat penting antar sufi yang mendahuluinya dan sufi sesudahnya. Barangkali inilah sebagian arti penting maksud 'penutup kewalian Muhammad'.

Kedua, Ibn al-'Arabi adalah penghubung antara tasawwuf Barat dan Timur. Tidak diragukan lagi, Ibn al-'Arabi dan ajarannya mempunyai pengaruh yang amat mendalam dan menyebar luas dan cepat, khususnya setelah kunjungannya ke Konya pada tahun 607 H./1210 M.dan mengambil Shadr al-Din al-Qunawi sebagai muridnya. Melalui hubungan Shadr al-Din al-Qunawi dengan sejumlah besar sufi terkemuka Persia inilah ajaran Ibn al-'Arabi sampai ke Timur. Cukuplah dikatakan bahwa Ibn al-'Arabi adalah guru Qutb al-Din al-Syirazi, Fakhr al-Din al-Iraqi (penyair mistis besar), sahabat karib Jalal al-Din Rumi (pengarang Matsnawi) dan seabad kemudian, seorang sufi 
besar, Abdul Karim al-Jilli, pengarang al-Insan al-Kamil.

\section{b). Wahdat al-Wujud, Konsepsi tentang Tuhan yang Melangit dan Membumi}

Konsep wahdat al-wujud merupakan konsep dasar metafisika Ibn al-'Arabi yang terkait erat dengan konsep insan al-kamil (manusia sempurna), inti sari ajaran tasawwufnya. Konsep wahdat al-wujud Ibn al-'Arabi berawal dari pandangan bahwa wujud dalam pengertian yang sebenarnya adalah realitas tunggal dan tidak dapat menjadi dua wujud, satu-satunya wujud itu adalah wujud Tuhan. Sementara wujudwujud yang lain selain wujud Tuhan hanyalah sebagai bayang-bayang dan merupakan penampakan dari semua kualitas-kualitas-Nya dalam wujud yang terbatas. Hal ini sesuai dengan ungkapan-ungkapan yang diutarakan oleh Ibn al-'Arabi sendiri, seperti : "Dia (al-Haqq, Tuhan) adalah esa dalam wujud, karena semua yang mungkin yang dapat dilihat, disifati dalam keadaan ini dengan ketiadaan. Semua yang mungkin itu tidak mempunyai wujud meskipun tampak bagi yang melihat” (Ibn al-'Arabi, 1972, 3:290). "Tiada yang tampak dalam wujud melalui wujud kecuali al-Haqq, karena wujud adalah al-Haqq, dan Dia adalah satu” (Ibn al-“Arabi, 1972, 2:517). "Entitas wujud adalah satu, tetapi hukum-hukumnya beraneka” (Ibn al-“Arabi, 1972, 2:519). ”Tidak ada keserupaan dalam wujud dan dan tidak ada pertentangan dalam wujud, karena sesungguhnya wujud adalah satu realitas dan sesuatu tidak bertentangan dengan dirinya sendiri” (Ibn al‘Arabi, 1980, 1:92). “...Wujud tidak lain dari al-Haqq karena tidak ada sesuatu pun dalam wujud kecuali al-Haqq" (Ibn al-“Arabi, 1972, 2:516).

Secara tekhnis Ibn al-'Arabi menggunakan istilah al-haqq dan al-khalq untuk menunjuk kedua pengertian wujud di atas. Al-haqq digunakan untuk menyebut esensi (substansi) dari semua fenomena dan al-khalq digunakan untuk menunjuk semua fenomena yang memanifestasikan esensi itu (Ibn al-'Arabi, 1980, 1:36 dan 2:35). Kedua istilah ini sebenarnya muncul hanyalah sebagai tanggapan dari akal semata dan tidak lain hanyalah sebutan bagi dua hal dari satu hakikat, yakni wujud Tuhan. Sebagaimana yang dikatakan oleh Ibn al-'Arabi sendiri : “ ...Tetapi al-Haqq dan al-Khalq adalah dua aspek bagi wujud yang satu atau realitas yang satu (Ibn al-'Arabi, 1980, 2:26).

Dengan demikian dapat dikatakan bahwa al-Khalq adalah cermin bagi al-Haqq dan al-Haqq merupakan cermin bagi al-Khalq. Al-Khalq sebagai cermin bagi al-Haqq menurut Ibn al-'Arabi mempunyai dua fungsi. Pertama, untuk menjelaskan sebab penciptaan alam. Karena tujuan Tuhan menciptakan alam adalah karena Dia ingin 
melihat dan mengenal diri-Nya dan ingin memperlihatkan dan memperkenalkan diriNya lewat alam (Ibn al-'Arabi, 1980, 1:48-9). Jadi, al-Haqq sebagai diri-Nya, sebagai Yang Mutlak akan tetap transenden, terasing dan tidak dapat dikenal oleh siapapun. Bahkan kata Ibn al-'Arabi Dia tidak dapat dikatakan Tuhan kalau tidak ada yang bertuhan kepada-Nya (Ibn al-'Arabi, 1980, 1:81). Yang kedua, untuk menjelaskan proses terjadinya yang banyak dari yang satu dan hubungan antara keduanya. Al-Haqq adalah satu, tetapi bentuk atau gambar-Nya banyak sebanyak cermin tempat bentuk atau gambar itu terlihat. Kejelasan gambar pada cermin tergantung pada kualitas kebeningan cermin itu. Dalam hal ini banyak tingkat kualitas kebeningan cermin. Cermin yang lebih bening, akan memantulkan gambar yang lebih jelas dan sempurna. Manusia adalah cermin yang paling sempurna bagi al-Haqq, karena manusia memantulkan keseluruhan nama-nama dan sifat-sifat al-Haqq pada diri-Nya. Sedangkan makhluk-makhluk yang lain memantulkan hanya sebagian nama-nama dan sifat-sifat itu. Di antara manusia yang paling sempurna kualitasnya adalah para nabi dan puncak kesempurnaan kualitas cermin itu terdapat pada 'cermin Muhammad' (Ibn al-'Arabi, 1972, 4:433).

Al-Haqq sebagai cermin bagi al-Khalq memunculkan persoalan yang cukup signifikan. Apakah manusia dapat melihat al-Haqq?. Dalam mensikapi persoalan tersebut Ibn al-'Arabi memberikan penjelasan bahwa manusia tidak melihat selain bentuknya sendiri dalam cermin al-Haqq. Ia tidak melihat al-Haqq dan tidak mungkin melihat-Nya meskipun ia mengetahui bahwa ia tidak mungkin melihat bentuknya yang sebenarnya kecuali pada-Nya (Ibn al-'Arabi, 1980, 1:61). Jadi, sebenarnya yang dilhat manusia bukanlah al-Haqq itu sendiri, tetapi merupakan penampakan-penampakan-Nya (tajalliyyat) melalui alam. Manusia dapat melihat al-Haqq melalui alam sebagai wadah tajalli (penampakan diri) al-Haqq. Proses tajalli al-Haqq ini, dibahas secara intensif oleh Ibn al-`Arabi sebagai penyokong konsep wahadat al-wujudnya.

Konsep tajalli al-Haqq dalam konsep wahdat al-wujud Ibn al-'Arabi memiliki peran yang sangat penting, karena tanpa merujuk kepada konsep ini, konsep wahdat alwujud dan hubungan ontologis antara al-Haqq dan al-Khalq tidak dapat dijelaskan. Konsep tajalli adalah merupakan titik sumbu pemikiran Ibn al-'Arabi, konsep dasar pandangan dunia Ibn al-'Arabi. Seluruh pemikirannya tentang struktur ontologis dunia berputar sekitar poros ini dan dengan demikian berkembang menjadi suatu sistem kosmik berskala besar. Tidak satu bagian pun dari pandangan dunianya dapat dipahami 
tanpa merujuk kepada konsep sentral ini. Kefilsafatan Ibn al-“Arabi adalah teori tajalli (Noer, 1995: 57).

Tajalli adalah proses penampakan diri al-Haqq, yang tidak dikenal secara absolut dalam bentuk-bentuk yang lebih konkrit. Tajalli al-Haqq terjadi secara terus menerus tanpa awal dan tanpa ahir, yang selama-lamanya ada dan akan selalu ada ( $\mathrm{al}$ da'im alladzi lam yazal wa la yazal) (Ibn al-'Arabi, 1980, 1:49). Tuhan melakukan tajalli dalam bentuk-bentuk yang tidak terbatas jumlahnya. Bentuk-bentuk itu tidak ada yang sama dan tidak pernah dan tidak akan terulang secara persis sama. Untuk memperkuat pandangannya, Ibn al-'Arabi mengutip pendapat Abu Talib Rijal Allah: "Sesungguhnya Allah selama-lamanya tidak melakukan tajalli dalam satu bentuk dua kali (Ibn al-'Arabi, 1980, 1:126). Konsep ini terkandung di dalam apa yang disebut sebagai 'penciptaan baru' yang berarti bahwa setiap ciptaan Tuhan adalah baru setiap saat, karena alam menjadi dan hancur, datang dan hilang, setiap saat secara terus menerus selama-lamanya.

Al-Haqq melakukan tajalli dalam setiap sesuatu sesuai dengan kesiapan (isti'dad) sesuatu tersebut, tidak kurang dan tidak lebih. Sebagaimana yang diungkapkan Ibn al-'Arabi dengan gaya bahasa yang khas bahwa "Allah memberi secara konstan, sementara lokus-lokus menerima (pemberian itu) sesuai dengan kadar realitas-realitas kesiapan lokus-lokus tersebut” (Ibn al-“Arabi, 1972, 1:287). Hal ini diumpamakan oleh Ibn al-'Arabi dengan cahaya yang dipancarkan matahari kepada benda-benda. Benda-benda menerima cahaya sesuai dengan kesiapannya. Orang, misalnya dengan temperamen dingin akan menikmati panas matahari, sedangkan orang dengan temperamen panas akan menderita karena panas matahari tersebut. Matahari memberikan cahaya dan panas yang sama, tetapi dua orang yang menerima cahaya dan panasnya itu memiliki keadaan yang berbeda, sehingga akibatnya pun berbeda pula, yang satu merasa nikmat dan yang lain menderita. Secara tekhnis, Ibn al-'Arabi juga menggunakan perumpamaan penerimaan suatu ayat al-Qur'an untuk menjelaskan sejauh mana tajalli diterima oleh sesuatu. Ayat al-Qur'an yang sama dipahami oleh tiga orang dengan pemahaman yang berbeda-beda sesuai dengan perbedaan kesiapan masingmasing dalam memahami ayat tersebut (Ibn al-'Arabi, 1972, 1:287). Ibn al-'Arabi berkata :

Hal yang sama berlaku juga pada tajalliyat (penampakan-penampakan diri) 
Tuhan. Pelaku tajalli (al-mutajalli), dari segi Dia sebagai diri-Nya adalah satu dalam entitas, sedangkan tajalliyat (penampakan-penampakan diri-Nya) berbeda sesuai dengan perbedaan kesiapan lokus-lokus tajalli. Sifat pemberian tuhan adalah sama (Ibn al'Arabi, 1972, 1:287).

Jadi, tingkat kemampuan setiap sesuatu untuk menerima tajalli al-Haqq ditentukan oleh kemampuan yang dimilikinya. Al-Haqq adalah Esa dan melakukan tajalli dalam ke-esaan-Nya. Namun, kesiapan masing-masing dari segala sesuatu dalam alam untuk menerima tajalli berbeda satu sama lain. Setiap sesuatu memiliki sifat-sifat dan situasi-situasi unik, karena itu ia memiliki kapasitas berbeda pula dalam menerima tajalli.

Dalam konsep tajallinya, Ibn al-'rabi juga menggunakan istilah emanasi (alfayd) sebagai sinonim kata itu. Menurutnya al-Haqq memiliki dua tipe utama emanasi, eamanasi paling suci (al-fayd al-aqdas) dan emanasi suci (al-fayd al-muqaddas) (Ibn al'Arabi, 1980, 1:49). Tipe pertama lebih dahulu dari pada tipe kedua hanya dalam logika urutan eksistensial, bukan dalam kenyataan. Emanasi paling suci disebut juga dengan penampakan diri esensial (al-tajalli al-dzati) dan penampakan diri ghaib (al-tajalli alghaybi). Tajalli dzati adalah taraf pertama yang paling menentukan dalam penampakan diri al-Haqq. Ia secara intrinsik hanya terjadi di dalam esensi Tuhan sendiri. Oleh karena itu, wujudnya tidak berbeda dengan esensi Tuhan itu sendiri, karena ia tidak lebih dari suatu proses ilmu Tuhan di dalam esensi-Nya sendiri.

Tajalli dzati menurut Ibn al-'Arabi terdiri dari dua taraf. Pertama, taraf ahadiyah dan kedua, taraf wahidiyah. Pada taraf ahadiyah, al-Haqq berupa wujud yang masih terlepas dari segala kualitas dan pluralitas apapun, tidak terkait dengan sifat, nama rupa, ruang, waktu, syarat sebab dan sebagainya. Al-Haqq belum menampakkan diri-Nya secara aktual dalam keanekaan. Dia masih mempertahankan keesaan asli-Nya. Yang banyak secara potensial masih Satu secara akltual. Jadi, al-Haqq betul-betul transenden atas segala-galanya. Di dalam transendensi-Nya itu Ia ingin dikenal oleh selain dari diriNya, maka diciptakan-Nya makhluk. Dari sebuah hadits Qudsi Ibn al-'Arabi mengutip : "Aku adalah harta terpendam (kanz) yang belum dikenal. Aku rindu agar dapat dikenal, maka $\mathrm{Ku}$ ciptakan makhluk. Aku memperkenalkan diri-Ku kepada mereka sehingga mereka mengenal-Ku” (Ibn al-“Arabi, 1972, 2:399). Jadi, dari taraf ahadiyah, tajalli 
dzati akan berlanjut pada taraf-taraf setelahnya sampai pada taraf di mana al-Haqq dapat dikenal oleh al-Khalq.

Selanjutnya, pada taraf wahidiyah, al-Haqq memanifestasikan dirinya secara ilahiyah yang unik, di luar batas ruang dan waktu. Taraf ini mereupakan taraf pertama ta'ayyunat (entifikasi-entifikasi) pada kodrat Wujud Absolut (Wujud Mutlak). Ia baru berada dalam akal dan belum mempunyai wujud dalam alam entitas-entitas yang dapat diindera (al-a'yan al-hissiyah). Ia baru semata-mata penerima wujud dan berada di dalam citra sifat-sifat-Nya. Realitas-realitas ini disebut Ibn al-'Arabi sebagai entitasentitas permanen (al-a'yan al-tsabitah) (Ibn al-'Arabi, 1980, 2:9). Kemudian, sifat-sifat tersebut terjelma dalam asma Tuhan. Apabila sifat-sifat dan nama-nama tersebut dipandang dari aspek ketuhanan, ia disebut asma ilahiyyah dan apabila dipandang dari aspek kealaman, ia disebut asma kiyaniyah. Aspek kedua, meskipun kelihatannya satu dengan aspek pertama, ia juga merupakan tajalli dari aspek pertama, karena pada asma kiyaniyah itu asma Tuhan mengambil bentuk entitas ('ayn) (Ibn al-'Arabi, 1972, 2:46970). Oleh karena itu, setiap kali asma ilahi muncul, ia senantiasa berpasangan dengan asma kiyaniyah sebagai wadah tajalli-Nya.

Dalam menjelaskan proses terjadinya tajalli pada taraf kedua dari tajalli dzati ini, secara tekhnis tampaknya Ibn al-‘Arabi mempunyai dua cara pengungkapan yang berbeda, dimana satu dengan yang lainnya kelihatan kontradiktif.

Dari dua cara tersebut di atas, sepertinya terdapat perbedaan proses terjadinya tajalli pada taraf wahidiyah secara tekhnis. Pada cara pertama, Ibn al-'Arabi meletakkan ama sebagai permulaan tajalli dan pada cara kedua ia menempatkan haba' sebagai permulaan tajalli. Akan tetapi apabila diperhatikan lebih cermat, akan tampak bahwa sebenarnya kedua istilah tersebut memang berbeda, ama, sebagaimana yang diungkapkan Ibn al-'Arabi di tempat lain, tidak lebih hanya sebagai lambang nafas Tuhan, yang terdapat pada taraf ahadiyah (Ibn al-'Arabi, 1972, 2:310). Sedangkan haba, terdapat pada posisi terakhir pada taraf wahidiyah dan merupakan materi prima yang menjadi dasar semesta, tetapi belum mempunyai wujud secara nyata (Ibn al'Arabi, 1972, 2:431-2). Jadi, dengan menempatkan ama pada taraf ahadiyah dan haba' sebagai awal pencitraan alam material yang menempati taraf wahidiyah, maka, kontradiksi tadi dapat dihilangkan. Namun, di antara para sufi ada yang kemudian cenderung untuk menempatkan suatu taraf tersendiri antara taraf ahadiyah dan 
wahidiyah, yaitu apa yang mereka sebut taraf wahdah. Kalau pada taraf ahadiyah Tuhan masih berada dalam ke-mujarradan-Nya dan pada taraf wahidiyah Tuhan bertajalli dengan nama-nama dan sifat-sifat-Nya pada potensi alam semesta, maka pada taraf wahdah Tuhan bertajalli dengan nama-nama dan sifat-sifat-Nya pada diri-Nya sendiri (Ali, 1997: 67).

Emanasi tipe kedua, yakni emanasi suci disebut juga penampakan diri eksistensial (al-tajalli al-wujudi) dan penampakan diri inderawi (al-tajalli al-syuhudi). Tajalli syuhudi adalah penampakan diri dari Yang esa dalam bentuk-bentuk keanekaan eksistensial. Tajalli ini merupakan penampakan 'entitas-entitas permanen' dari alam yang ada hanya dalam pikiran kepada alam yang dapat diindera, atau penampakan apa yang potensial dalam bentuk apa yang aktual, dan munculnya segala yang ada secara eksternal sesuai dengan apa yang ada dalam kepermanenan azalinya. Tidak ada sesuatu apapun dalam wujud penampakannya menyalahi apa yang ada dalam kepermanenannya sejak azali (Ibn al-'Arabi, 1980, 1:866).

Pada taraf tajalli syuhudi, al-Haqq menampakkan diri-Nya dalam berbagai bentuk yang tidak terbatas dari yang banyak dalam alam wujud yang konkrit. Pada taraf ini terjadi segala sesuatu, mencakup tidak hanya substansi-substansi, tetapi juga sifatsifat perbuatan-perbuatan dan peristiwa-peristiwa. Entitas-entitas permanen yang telah diwujudkan tajalli dzati, meninggalkan keadaan wujud intelligible, menyebarkan dirinya dalam segala sesuatu yang inderawi, dan dengan demikian menyebabkan alam inderawi ada dalam aktualitas (Noer, 1995: 63).

Proses hirarki tajalli syuhudi secara lebih rinci dapat digambarkan sebagai berikiut : Pada tahap awal, yang pertama sekali muncul adalah al-jism al-kulli (jasad universal) sebagai penampakan lahir dari nama-nama Tuhan, al-Zhahir (Yang Mahanyata). Kemudian pada tahap berikutnya, jasad universal tersebut mengambil bentuk al-syakl al-kulli (bentuk universal), sebagai efek dari tajalli Tuhan dengan namanya, al-Hakim (Yang Mahabijaksana). Selanjutnya, Tuhan dengan nama-namaNya, al-Muhith (Yang Mahameliputi), al-Syakur (Yang Mahamelipatgandakan pahala), al-Ghani (Yang Mahakaya) dan al-Muqtadir (Yang Mahamemberi kekuasaan). Masingmasing menampakkan diri pada arasy (singgasana) Tuhan, kursi, falak al-buruj (falak bintang-bintang) dan falak al-manazil (falak berorbit). 
Setelah falak al-manazil, secara berturut-turut muncul langit pertama, hingga langit keenam dan langit dunia. Kemudian muncul pula eter, api, udara, air, tanah, mineral, tumbuh-tumbuhan, hewan, malaikat, jin, manusia dan manusia sempurna. Masing-masing merupakan tajalli dari nama-nama Tuhan, al-Rabb (Yang Maha Mengatur), al-Alim (Yang Maha Mengetahui), al-Qahir (Yang Mahaperkasa), al-Nur (Yang Maha Bersinar), al-Mushawwir (Yang Membentuk rupa), al-Muhshi (Yang Mencatat), al-Matin (Yang Mahakokoh), al-Qabidl (Yang Membatasi), al-Hayy (Yang Mahahidup), al-Muhyi (Yang Menghidupkan), al-Mumit (Yang Mematikan), al-'Aziz (Yang Mahamulia), al-Razzaq (Yang Memberi rizki), al-Mudzil (Yang Menghina), alQawi (Yang Mahakuat), al-Lathif (Yang Mahaluas), al-Jami' (Yang Menghimpunkan), Rafi' al-Darajat (Yang Mahatinggi derajat-Nya). Pada peringkat manusia sempurna itulah kesempurnaan tajalli Tuhan terjadi pada makhluq, karena pada manusia sempurna semua nama-nama dan sifat-sifat Tuhan termanifestasikan (Ibn al-'Arabi, 1972, 2:433).

Tajalli dzati dan tajalli syuhudi memiliki hubungan yang sangat erat dalam kaitannya dengan hati (qalb), khususnya hati sang gnostik (qalb al-'arif).

Hirarki tajalli al-Haqq secara keseluruhan dapat disimpulkan sebagai berikut. Pertama, tajalli terjadi berbentuk penampakan diri al-Haqq kepada diri-Nya sendiri dalam bentuk entitas-entitas permanen. Entitas-entitas permanen ini adalah realitasrealitas yang hanya ada dalam ilmu Tuhan dan tidak ada dalam alam nyata. Ia tidak lain daripada bentuk-bentk penampakan nama-nama Tuhan pada taraf kemungkinankemungkinan ontologis. Ia juga yang selama-lamanya tidak berubah dan tidak dapat diubah, memberikan kesiapan azali kepada lokus untuk tajalli berikutnya. Tajalli kedua terjadi ketika kesiapan azali diterima oleh lokus ini, yang menjadi tempat penampakan al-Haqq. Tajalli kedua adalah penampakan entitas-entitas permanen dari alam gaib ke alam nyata, dari potensialitas ke aktualitas, dari keesaan ke keanekaan. Pada saat yang sama secara serentak kesiapan azali menampakkan diri dalam bentuk kesiapan partikular yang diterima setiap sesuatu di alam ini, yang menjadi lokus penampakan diri al-Haqq. Pada tajalli kedua ini, al-Haqq menampakkan diri-Nya dalam bentuk-bentuk yang tidak terbatas dalam alam nyata. Totalitas semua bentuk ini merupakan alam nyata. Alam dan segala sesuatu yang ada di dalamnya mempunyai wujud persis seperti apa yang telah ada sejak azali dalam entitas-entitas permanen. 
Jadi, al-Haqq seperti yang dikatakan Ibn al-'Arabi berkenaan dengan diri-Nya sendiri mempunyai ketunggalan dari Yang Satu, tetapi berkenaan dengan nama-nama dan sifat-sifat-Nya Dia mempunyai ketunggalan dari Yang Banyak (Ibn al-'Arabi, 1980, 1:90 dan 2:85). Begitu pula al-Khalq apabila dilihat dari aspek ketuhanan ia adalah Realitas Absolut itu sendiri dan apabila dilihat dari aspek kemakhlukan ia adalah segala sesuatu yang relatif, yang lain dari Realitas Absolut. Jadi, makhluk qua makhluk dapat dibedakan dan harus dibedakan dengan Tuhan, namun, kemakhlukan juga dapat direduksi menjadi kodrat ketuhanan sejauh yang pertama adalah hubungan iluminatif dari yang terakhir.

\section{c). Menjadi Insan al-Kamil, Merasakan Tuhan di Bumi}

Ibn al-'Arabi (1972: 4:323) berpendirian bahwa hati adalah alat yang dengannya dapat mencapai makrifat kepada Allah SWT. dan rahasia-rahasia ketuhanan. Ia merupakan realitas manusia yang lembut yang sudah memadai untuk pengungkapan diri Tuhan. Karena ia tidak dapat diperbandingkan dan sekaligus sama. Tuhan juga tidak dapat dijangkau tapi sekaligus hadir. Hati merupakan substansi yang bercahaya dan terpisah antara ruh dan jiwa. Hati terjebak di antara keduanya. Kadang-kadang ia ditarik menuju cahaya dan kebahagiaan. Kadang-kadang ia menuju kegelapan dan kesengsaraan. Jika ia naik menuju ruh, ia akan mencapai kesempurnaannya sebagai 'jiwa rasional'. Dan jika ia turun menuju jiwa yang dikuasai oleh batasan-batasan badaniah, ia akan terputus dari cahaya itu (Murata, 1999: 389-390). Jadi, ketika hati mencapai kesempurnaan perwujudan dalam diri manusia yang sempurna, ia akan menampilkan Tuhan dalam pengungkapan diri-Nya yang tak terbatas. Dan ketika hati bergerak menuju kenistaan, ia akan menjauh dan terasing dari eksistensinya dan dari Tuhannya.

Demikianlah, maka untuk menimbang segala amalan-amalan aktual manusia, Tuhan pun menggunakan hati sebagai tolok ukurnya. "Tidak ada celanya jika kamu berbuat salah, kecuali jika hatimu menyengajanya”.(QS 33:5). “Tuhan tidak akan menghukummu karena sumpah yang tidak disengaja, tetapi Tuhan akan menghukummu karena sumpah yang disengaja oleh hatimu. Dan Tuhan maha pengampun lagi maha penyantun” (QS 2:225). Bandingkan dengan QS 2:118 dan QS 8:70. Sebuah hadits mengatakan bahwa "Tuhan tidak melihat badanmu atau bentukmu, melainkan ke dalam hatimu”. (HR Muslim). 
Hadits itu menunjuk betapa manusia yang fisis (sesungguhnya) telah menyatu dengan Tuhan yang non-fisis dan diinstruksikan bisa melihat-Nya melalui instrumen diri sendiri yang fisis. Dengan kata lain, manusia adalah 'citra Tuhan' yang paling sempurna. Manusia merupakan makhluk teomorfis, merupakan wadah tajalli Tuhan, tempat pengejewantahan nama-nama dan sifat-sifat Tuhan. Ia memiliki 'hadiah istimewa' dari Tuhan berupa kemampuan memanifestasikan dirinya atas semua namanama dan sifat-sifat Tuhan. Artinya, sebenarnya manusia memiliki potensi untuk 'menjadi Tuhan'. Karena dengan sifatnya tersebut, manusia dapat memperlihatkan variasi tidak terbatas nama-nama dan sifat-sifat Tuhan secara utuh, bersatu dan terkonsentrasi. Berbeda dengan alam selain manusia yang hanya memanifestasikan sebagian dari nama-nama dan sifat-sifat Tuhan secara terpisah dan menyebar di berbagai tempat di alam semesta.

'Kado istimewa' Tuhan bagi manusia juga diberikan dalam wujud pengajaran semua nama-nama benda kepada manusia pertama, Adam. Saking cintanya kepada manusia dengan begitu tulus Tuhan menganugerahkan kepada manusia suatu posisi yang luar biasa, yakni sebagai khalifah (wakil)-Nya dimuka bumi. "Aku menciptakan di muka bumi seorang khalifah" (QS 2:30). Jadi, sebenarnya memang sudah dari sononya manusia memiliki 'hubungan dekat' dengan Tuhan. "Tuhan sesungguhnya lebih dekat kepada manusia dibanding dengan dekatnya manusia kepada dirinya sendiri”. (QS 50:16), Saking dekatnya, sampai tidak terlihat. Maka ajaran manunggaling kawulo-gusti (wahdat al-wujud) tidak hanya dipahami melalui kurikulum sufistik saja, (misalnya) dengan ekstasi total yang dapat menengelamkan diri larut dalam lautan diri Tuhan (istigraq fi bahr al-wihdah) sehingga secara tak sadar kadang terucap kata-kata 'murtad' yang membimbangkan kaum fuqaha eksoteris, seperti 'Ana al-Haqq' ucapan al-Hallaj, 'Subhani, subhani ma a'dama sya'ni' ucapan Abu Yazid al-Busthami (w. 261 H), 'Ma fi jubbati illa Allah' ucapan Abu Ali bin Abi Thalib al-Farisi, dan lain-lain.

\section{SIMPULAN}

Sampai disini, konsep wahdat al-wujud dan potensi manusia atas manifestasi wujud Tuhan itu tidak dipahami bahwa Tuhan identik dengan manusia atau alam sebagaimana gagasan yang diusung oleh paham panteisme, sebuah konsep teologi yang diusung oleh para pemikir Barat. Paham ini beranggapan bahwa semua yang ada pada keseluruhannya adalah Tuhan, dan Tuhan adalah semua yang ada sebagai 
keseluruhannya. Tuhan dan alam adalah satu realitas atau satu wujud. Di sini imanensi Tuhan terlihat secara total dan transendensi-Nya hilang, perbedaan esensial antara Tuhan dan alam tidak ada lagi (Noer, 1995: 2). Dalam teologi dan sufisme Islam, wujud alam atau manusia dipahami hanyalah dalam pengertian metaforis (majazi) saja, bukan menurut hakikatnya. Apa yang terlihat sebenarnya bukanlah hakikat alam, namun wujud itu sendiri, yakni Tuhan al-Haqq ketika tidak ada lagi eksistensi yang membolehkannya menjadi terlihat (Chittick, 2001: 31).

\section{DAFTAR PUSTAKA}

Ibn al-'Arabi, 1972, Al-Futuhat al-Makkiyyah, Ed. Usman Yahya, Mesir:Al-Hai'at alMisriyyah al-Ammah li al-Kitab. , 1980, Fushus al-Hikam, Ed. AE. Afifi, Beirur:Dar al-Kitab al-‘Arabi.

Ali Yunasril, 1997, Manusia Citra Ilahi, Jakarta:Paramadina.

Chittick William C., 2001, Dunia Imajinal Ibnu 'Arabi, Terjemahan Achmad Syahid dari Imaginal World, Ibn al-'Arabi and The Problem of Religious Diversity, Surabaya:Risalah Gusti.

Danner Victor, 1999, Mistisisme Ibnu 'Atha'illah, Terjemahan Roudlon dari Ibn 'Athai'illah's Shufi Aphorisms, Surabaya: Risalah Gusti.

Murata Sachiko, 1999, The Tao of Islam, Terjemahan Rahmani Astuti dan M.S. Nasrullah dari The Tao of Islam, Bandung:Mizan.

Noer Kautsar Azhari, 1995, Ibn al-'Arabi:Wahdat al-Wujud Dalam Perdebatan, Jakarta:Paramadina.

Zaini M. Fudoli, 2000, Sepintas Sastra Sufi: Tokoh dan Pemikirannya, Surabaya:Risalah Gusti.

Austin RWJ., 1994, Sufism Of Andalusia, terjemahan MS. Nasrullah dari Ruh al-Quds dan Durrat al-Fakhirah, Bandung:Mizan. 